doi:10.7592/TF10.foorum

\title{
Kohtumispaik internetifoorum. Sissevaateid virtuaalrühma kollektiivsusse ${ }^{1}$
}

\section{Maili Pilt}

Teesid: Artiklis otsin vastust küsimusele, milles seisneb virtuaalrühma kollektiivsus, vaadeldes kahe eestikeelse internetikeskkonna, Perekool (www.perekool.ee) ja Kodutud (www. kodutud.com) foorumeid. Probleemipüstituse ajendiks on olnud tõdemus, et internetikasutajad ei ole ühtne siserühm, ning et niinimetatud virtuaal- või internetirühmad ${ }^{2}$ ei moodustu päris samadel alustel kui kooslused väljaspool internetti. Käsitlus on kasvanud välja huvist folkloristliku välitöösituatsiooni ja sellega seotud uurijaeetika küsimuste vastu. Sellest tulenevalt kasutan terminit "kohtumispaik" kahes tähenduses: nii virtuaalrühma liikmete igapäevase suhtlusruumina kui ka "väljana", kus kohtuvad uurija ja uuritavad.

Käsitlusel on kaks sihti: 1) leida vastus küsimusele, milles seisneb virtuaalrühma kollektiivsus analüüsitud internetikeskkondades - see annab aimu foorumeisse kirjutatud tekstide sotsiaalkultuurilisest kontekstist, 2) teha selle põhjal järeldusi, millist abi võiks saadud teadmistest olla foorumitekstide salves-

${ }^{1}$ Uuringut toetas Euroopa Liit Euroopa Regionaalarengu Fondi kaudu (Kultuuriteooria Tippkeskus).

${ }^{2}$ Shawn B. Wilbur $(1997,14)$ on märkinud, et mõiste "virtuaalne kogukond" (Virtual Community) ei pruugi tingimata olla seotud arvutite vm kõrgtehnoloogiaga. See võib olla ka nt rühm sarnastest saadetest huvitatud televaatajaid, kogukonna simulatsioon (nt Disneyland) vm viisil loodud illusioon kogukonnast. Käesolevas käsitluses on mõisteid "virtuaalne kogukond", "virtuaalrühm" ja "internetirühm” kasutatud sünonüümidena. 
tamisel ja uuritavatega suhtlemisel uurijale, kelle huvikeskmes on neisse foorumeisse kirjapandud kogemuslood. ${ }^{3}$

Märksõnad: folkloristlikud välitööd, internetifoorum, kollektiivsus, "paigad" virtuaalmaastikul, uurijaeetika, virtuaalrühm

\section{Sissejuhatus: rahvaluulest, kollektiivsusest ja internetist}

Rahvaluulet ehk folkloori seostatakse kollektiivsusega. Alan Dundes on oma klassikaks saanud definitsioonis osutanud, et folkloristika üks keskseid mõisteid "rahvas" võib tähistada mis tahes inimeste rühma, kellel on vähemalt üks ühine tunnus - tähtis on, et mis tahes põhjusel formeerunud rühmal oleksid traditsioonid, mida ta peab omaks. Rahva mõiste eeldab Dundesi järgi midagi kollektiivset, mitmuslikku vormi (Dundes 2002, 17, 26). Teose "Folklore and the Internet. Vernacular Expression in a Digital World" (Folkloor ja internet. Rahvapärane väljendusviis digitaalses maailmas) koostaja Trevor Blank on märkinud, et aktsepteerides Alan Dundesi paljutsiteeritud pärimusrühma definitsiooni, märkame, et internet on elujõuline ja oluline väli uurimistöö läbiviimiseks (Blank 2007, 19). Erinevatest internetikeskkondadest võib leida hulgaliselt folkloristide huvisfääri kuuluvat ainest: interneti teel levivad anekdoodid, linnalegendid, kettkirjad, uskumused, kalendrikombestik, rahvameditsiin, kogemuslood või internetikeskkonnale spetsiifilised nähtused nagu nt arvutiklaviatuuri märkidest loodud pildid (nn ASCII-kunst) ning kasutajanimed.

Kuigi pärimuslik aines tekib ja levib ühtviisi nii internetis kui ka väljaspool seda, on protsesside toimumise kontekst erinev. Silmast silma kohtumistel mängib pärimusrühma moodustamisel esmajärgulist rolli vahetu suhtlus, reaalne asupaik, sugulussidemed, osapoolte füüsiline väljanägemine, rahvus, sugu vm, internetis

${ }^{3}$ Internetifoorumeisse kirjutatud kogemuslood on mina- või meie-vormis, (sageli väga isiklikke) tundeid ja hinnanguid sisaldavad tekstid, mis kirjeldavad foorumiliikmete või nende lähedaste argielu või tähtsündmustega seotud kogemusi. Pere- ja suhtefoorumites esinevad kogemuslugudest näiteks sünnituslood, suhtelood, lood naljakatest juhtumitest, samuti lood üleloomulikest kogemustest. Oma uurimuses huvitun nende tekstide ülesehitusest ja sisust, kirjutajate ajendeist ning kollektiivsest kirjutamissituatsioonist, kus neid tekste luuakse. 
mõjutavad pärimusrühma kollektiivsust (ühisosa, mille alusel rühm moodustub) inimeste füüsilise kohalolu puudumine, suhtluse tekstipõhisus ja konkreetse virtuaalkeskkonna eripära.

Virtuaalkogukondadega seonduvat probleemistikku analüüsinud Derek Foster $(1996,25)$ on viidanud, et internetile sobib hästi Benedict Andersoni teoses "Imagined Communities" (1983) postuleeritud idee kujutletud kogukondadest. Fosteri sõnul mõjub arvutivahendatud suhtlus soodsalt kujutlusvõimele, kutsudes esile ühtekuuluvuse näota, põgusate ja anonüümsete "teistega". Uurijad on virtuaalrühmade kollektiivsust iseloomustades tõstnud esile veel vabatahtliku osaluse, ühistest huvidest ja väärtustest tuleneva vastastikuse kommunikatsiooni kirjutamise ja lugemise teel ja tehnoloogiliste piirangutega koha virtuaalmaastikul (vt nt Arpo 2001, 25, 31; Fernback 1999, 211-212; Foster 1996, 29; Healy 1996, 57; Rheingold 1993).

Rühmade moodustumist internetis on kirjeldatud seoses "paiga" või "koha" mõistega, sest virtuaalruumis on nähtud analoogiat inimeste kohtumispaikadega väljaspool internetti. Internet ei ole pelgalt "globaalne küla" nagu seda aeg-ajalt nimetatakse, vaid see sisaldab eriilmelisi ja erinevaid suhtlusviise võimaldavaid keskkondi. Rühma kogunemis- ja kohtumispaik (ning ühtlasi folkloristlik uurimisväli) virtuaalmaastikul võib olla veebileht, rollimängudele keskenduvad MOO või MUD, reaalaja-jututuba (IRC), foorum, postiloend, virtuaalne päevik ehk blogi, kuid ka näiteks ajalehe või ajakirja veebiväljaande kommentaarium või isikliku sotsiaalse võrgustiku loomist võimaldav keskkond nagu Facebook (vt ka Blank 2009; Kalda 2010a; Kõiva, Vesik 2009; Rheingold 1993; Vesik 2008, 2010). Sellised kohad ja nende ümber tekkivad rühmad on olemuselt erinevad. See on põhjendus, miks on käesolevas käsitluses keskendutud just ühele spetsiifiliste tunnustega paigale virtuaalmaastikul - internetifoorumile.

Katja Laitinen (2003, 249-250) eritleb folkloristide ja ühiskonnateadlaste kollektiiviuurimusi, kuna folklorist ei määratle (uuesti!) kollektiivi mõistet, vaid vaatleb just nimelt kollektiivsust kultuurivormina. Virtuaalrühma kollektiivsuse ilmingud on Eesti folkloristide töödes varem tähelepanu pälvinud seoses pere-, meditsiini-, lemmiklooma-, geopeituse- ja esoteerikafoorumitega. Reeli Reinaus on vaadelnud pärimuslikku ainest Perekooli foorumites seoses rühmaliikmete käitumismustrite ja eneseesitlusviisidega, juhindudes pärimusrühma identiteedist (vt Reinaus 2008a, 2008b, 
2008c). Mare Kalda (2009, 2010b) on geopeituse käsitlustes analüüsinud foorumiliikmete ühiste huvidega seotud käitumisviise ning enesepresentatsiooni protsesse, ajendatuna ühe ja sama nähtuse vaatlusest internetis ja sellest väljaspool. Liisa Vesik $(2008,2010)$ on vaadelnud foorumiliikmete kattuvaid huvisid, väärtushinnanguid, eneseesitlusviise, soolist koosseisu jm seoses muutustega lemmikloomadega seotud veebikogukondades. Otsides vastust küsimusele, kas internetiühiskonnad võiksid asendada varasemaid sotsiaalseid ja perekondlikke kooslusi, on Mare Kõiva (2009, 2010) käsitlenud online-meditsiini, foorumite kommunikatsiooniviise ja narratiive. Reet Hiiemäe on vaadelnud esoteerikafoorumite näitel virtuaalidentiteedi loomist (sh vanema usundilise traditsiooni ja mütoloogia motiivide kasutamist), rollikäitumise seaduspärasususi, funktsioone ja eesmärke (vt Hiiemäe 2010).

\section{Käesolev probleemipüstitus}

Minu huvi virtuaalrühma kollektiivsuse vastu kasvas välja välitöömetoodika ja uurijaeetika käsitlemisest kogemuslugudele keskendunud uurimistöös. 2005. aastal sünnipäevatraditsioone uurides puutusin kokku internetikeskkonna Perekool foorumiliikmete jutustustega sünnipäeva tähistamise kogemustest, samuti lähikondsete eest varjatud tunnetest. Neid tekste vaadeldes ja ise foorumivestlusi algatades kogesin, et kuigi uurija käsutuses olevad välitöömeetodid ja uurimise käigus lahendamist nõudvad eetikaküsimused sarnanevad neile, mida kogeme uuritavatega vahetult silmast silma kohtudes, ${ }^{4}$ on internetifoorumi-põhisel uurimistööl oma eripära, millega tuleks arvestada. Internet võimaldab koguda uurimismaterjale uuritavate eest varjatult ja anonüümselt. Uuritavad osalevad oma tavapärases spetsiifiliste tehnoloogiliste võimaluste ja piirangutega, aja jooksul kujunenud suhtlusviiside ja traditsioonidega virtuaalruumis. Kas ja kuidas peab vaatleja teavitama foorumiliikmeid oma uurijahuvist, kuidas saab uurimistööd läbi viia, kahjustamata uuritavate huve, kuidas on võimalik saada luba tekstide tsiteeri-

\footnotetext{
${ }^{4}$ Internetifoorumis saab välitöömeetoditena kasutada vaatlust, osalusvaatlust, rühmavestlust ja privaatteadete saatmise võimaluse olemasolul ka individuaalset intervjuud. Küsimused kontakti saavutamisest, nõusoleku saamisest ja uuritavate privaatsuse tagamisest tulevad internetifoorumis samamoodi esile kui väljaspool internettigi.
} 
miseks? Internetifoorumite ligipääsetavuse tõttu näivad foorumid avaliku ruumina, kuhu postitatut, sh kogemuslugusid võivad lugeda kõik internetikasutajad, samas on kogemuslugude privaatne sisu, väga isiklik ja tundlik informatsioon vastuolus foorumi avatusega. Kogemustest kirjutajad ei ole tõenäoliselt endale teadvustanud, et nende tekstid võivad saada mõne uurimuse objektiks ja muutuda avalikuks väljaspool konkreetset virtuaalruumi (vrd ka Roberts, Smith, Pollock 2004, 161).

Mõistmaks foorumeisse kirjutatud tekstide sotsiaalkultuurilist konteksti, vaatlen käesolevas käsitluses üksikasjalikumalt mind huvitavate virtuaalrühmade kollektiivsuse ilminguid. Ühtlasi otsin selle abil vastust küsimusele, kuidas peaks uurija käituma foorumikeskkonnas suheldes ja/või vaatluse teel inimeste kogemusi, tundeid ja arvamusi sisaldavaid tekste kogudes. Probleemipüstituse vajalikkust kinnitavad Robert Arpo ja Trevor J. Blanki käsitlused. Arpo $(2001,26)$ tõdeb, et internetitekstide lugeja peab teksti mõistmiseks tundma seda loonud kollektiivi. Trevor J. Blank $(2009,11)$ osutab teose "Folklore and the Internet" sissejuhatuses, et folkloristlik välitöö internetis võiks alata inimesest, kuna folkloristidena peame endalt küsima, kes on rahvas (küberrahvas) kübermaailmas, mis eristab neid traditsioonilisest rahvast ning millised piirangud või vajadused määravad, kuidas esineb rahvas interneti kontekstis.

Analüüsi aluseks on eestikeelsete veebilehtede Perekool ja Kodutud foorumid. Perekool, Eesti Ämmaemandate Ühingule kuuluv keskkond, loodi 2000. aastal. Sealt võib leida informatsiooni pere planeerimise, laste kasvatamise ja pereeluga seotud teemadel. Keskkonnas saab lugeda teemakohaseid artikleid ja küsida nõu spetsialistidelt. Käesoleva artikli kirjutamise ajaks oli foorumil üle 85000 registreerunud kasutaja. ${ }^{5}$ Kodutute foorumid algatas 2002. aastal tänaseni foorumi meeskonda kuuluv Mada. ${ }^{6}$ Algselt kandis foorum oma looja nime ja sel ei olnud kindlat sihti. Ajapikku kujunes sellest täiskasvanutele mõeldud suhtefoorum, mis foorumiliikmete ühise mõttetöö tulemusena hakkas kandma nime "Kodutud". ${ }^{7}$ Lisaks vestlusfoorumitele sisaldab Kodutute internetikeskkond vahetut suhtlemist võimaldavat jututuba, pildigaleriid ja tutvumiskuulutuste rubriiki. Foorumisse ülesriputatud liikmete nimekirja kuulus

\footnotetext{
${ }^{5}$ Info statistika kohta pärineb kirjavahetusest Perekooli keskkonna juhataja Elina Piirimäega.

${ }^{6}$ Tegemist on kasutajanimega.

7 "Järjejutt: foorum läbi aegade" (K40); "Fooruminimi" (K45).
} 
käsitluse kirjutamise hetkel üle 25000 registreeritud kasutaja. Neist umbes kolmkümmend on olnud aktiivsed osalejad foorumi algusaegadest peale.

Meetoditest olen kasutanud vaatlust ja osalusvaatlust. Perekooli foorumeid jälgisin aastatel 2003-2012. Selles keskkonnas tundsin end aeg-ajalt ka mõne ajutise siserühma ${ }^{8}$ liikmena, kuna osalesin lisaks vaatlusele $\mathrm{ka}$ ise foorumivestlustes. Kodutute foorumeid jälgisin aastail 2010-2012. Olen sealsete foorumite registreerunud kasutaja, kuid seniajani kõrvalseisja ja vaatleja. Vaatlused ja foorumipostitused, millele käesolevas artiklis viitan, on salvestatud isiklikku arvutisse ja varustatud järjekorranumbriga. Viited märgistusega "K" pärinevad Kodutute keskkonna foorumeist, viited märgistusega "P" Perekooli foorumeist. Kodutute foorumite liikmed, kelle postitusi olen tsiteerinud koos profiiliandmetega, on selleks andnud isikliku nõusoleku.

\section{Virtuaalrühma kollektiivsus}

Dorothy Noyes $(2003,10)$ on täheldanud, et ühe ja sama sündmusega võivad olla seotud erinevad kollektiivsuse definitsioonid (iga päev suhtlev rühm, ühishuvidega seotud rühm, tavapärase piirkonna järgi moodustuv rühm, seotud järeltulijate rühm, territoriaalne rühm, sooline rühm, konkreetsest esitusest tulenev rühm vm). Eelkirjeldatud probleemipüstituse kontekstis on esile tulnud neli aspekti: rühmaruum, kirjutatud ja kirjutamata reeglid, ühishuvid, ajaviited ja sündmused, eneseesitlus ja rollikäitumine.

${ }_{8}^{8}$ Ajutiste siserühmade all pean silmas mõne alamfoorumi sees aeg-ajalt esilekerkivaid väiksemaid rühmi, mille liikmed hakkavad omavahel aktiivselt suhtlema mõne nende elus esiletuleva või tähendusliku sündmuse tõttu. Kui sündmus minetab oma aktuaalsuse, laguneb rühm koost (nt vahetavad Perekooli lapseootuse alamfoorumis aktiivselt informatsiooni ja kogemusi maikuus sündivate laste vanemad, pärast lapse sündi aga rühma suhtlus teatud põhjustel vaibub (mõnel vanemal pole enam piisavalt aega foorumis osaleda, teised "kolivad" üle alamfoorumisse "Beebi" või mõnda teise pereteemasid käsitlevasse veebikeskkonda). 


\section{"Rühmaruum" - internetifoorum}

Vaadeldavate rühmade liikmeid ühendab virtuaalmaastikul modereeritud $^{9}$ (s.o kontrollitud suhtlusega) temaatiline internetifoorum ehk uudisrühm, kuhu liikmed saavad oma sõnumeid postitada otse, moderaatorid kontrollivad ja otsustavad juba avalikkusele kättesaadavate tekstide sobivuse üle. Foorumitel on püsiv veebiaadress, neid iseloomustavad universaalsed tehnoloogilised võimalused: teksti-, vähesel määral ka pildipõhine asünkrooniline rühmavestlus, uute vestlusteemade lisamise võimalus, spetsiifilised eneseesitlusvahendid ja anonüümsuse lubatus.

Internetiuurijate seas palju tsiteeritud teose "The Virtual Community: Homesteading on the Electronic Frontier" autor Howard Rheingold on näinud internetifoorumeis sarnasust Ray Oldenburgi (1999) kirjeldatud nn kolmandate paikadega nagu kohvikud, pubid ja linnaväljakud. Need paigad asuvad neutraalsel pinnal, vestlus on neis paigus põhitegevus ning inimeste personaalsuse ja individuaalsuse näitamise ja tunnustamise käivitaja (vt Rheingold 2000). Ka Perekooli ja Kodutute foorumites osalejad saavad algatada vestlusteemasid, lugeda teiste algatatud teemasid ja neile vastata. Foorumi ülesehitus soodustab rühmasuhtlust, mis areneb küsimus-vastus stiilis või on pikem teemajutustus, millele oodatakse samaga vastamist ja/või hinnangut. Iga postituse juures on nähtav, millal viimati vastati, millise kasutajanime alt on see postitatud ja milline on vastuste koguarv. Kodutute foorumid näitavad infot ka selle kohta, mitu korda on teemat vaadatud, andes ülevaate nn hiilijate - foorumi liikmete või külaliste - kohalolust, kes jälgivad foorumisuhtlust, ise sellesse aktiivselt sekkumata (vrd Rheingold

9 Teose Virtual Ethnography (Virtuaalne etnograafia) autor Christine Hine $(2000,160-161)$ on interneti terminite sõnastikus eristanud modereeritud ja modereerimata uudisrühmi (inglise keeles vastavalt moderated newsgroup ja unmoderated newsgroup). Modereeritud uudisrühm on Hine’i järgi foorum, mille üks liige, s.o moderaator, vaatab üle kõik postitatud sõnumid ja otsustab nende sobivuse üle, enne kui lisab need foorumisse. Sõnumeid saab postitada ainult moderaatori vahendusel. Modereerimata uudisrühm on foorum, kuhu iga kasutaja saab sõnumeid postitada otse, moderaatori vahendamiseta. Käesolevas käsitluses analüüsitavad foorumid on midagi Hine'i kirjeldatud foorumite vahepealset - nende foorumite liikmed saavad oma sõnumeid foorumisse postitada otse ning moderaatorid kontrollivad ja otsustavad juba avalikkusele kättesaadavate tekstide sobivuse üle. 
2000). Perekooli ja Kodutute keskkonna avalike foorumite ülesehitus ei soodusta kahe inimese eravestlusi, vaid loob tingimused kolme või enama osaleja suhtluseks (vestlusel võib olla teadmata arv vaikivaid "pealtkuulajaid"). Kodutute keskkonnas saab privaatvestlusteks kasutada suhtlusvahendit U2U. ${ }^{10}$ Perekooli foorumites on osalejad mõnikord lisanud oma postitustele meiliaadressi, mille kaudu saab nendega eravestluseks ühendust võtta.

Aeg ja ruum internetis on vastuolus tavapäraste arusaamadega ajast ja ruumist füüsilises maailmas (Arpo 2001, 28). Trevor Blank $(2007,20)$ on internetist kui folkloristlikust uurimisväljast kõneledes juhtinud tähelepanu, et interneti kontekstis võib "väli" olla samal ajal erinevates kohtades ning inimesed võivad osaleda ühes ja samas vestluses eri aegadel (vt ka Fialkova, Jelenevskaja 2001). Nii Perekooli kui ka Kodutute foorumite suhtlus on oma olemuselt asünkrooniline. Vestlusega saab ennast maailma eri paigust kurssi viia ja sõna sekka öelda igal ajal, nii ööl kui päeval. Vestlus, mis silmast silma kestaks tund või paar, võib internetifoorumis väldata päevi, nädalaid või koguni kuid, ${ }^{11}$ täna esitatud küsimusele võib vastata homme jne (vrd ka Wallace 2002, 18-20). Asünkroonilist vestlust võimaldab asjaolu, et foorumid salvestavad ja arhiveerivad tekstid nende postitamise hetkel. Uued teemad lükkavad vanemad teemaderivis tahapoole, moodustades lehekülgede pikkusi nimistud, mida on võimalik taas ja taas üle lugeda ning naasta vestluse edenedes kerge vaevaga selle alguses käsitletud probleemide juurde. Perekooli keskkonnas võivad foorumi liikmed tänu postituste arhiveerimisele "mängida" aja ja ruumiga, kasutades foorumi pakutavaid vahendeid nagu "Muuda" (toimib 24 tunni jooksul pärast postitamist) ja "Kustuta" (toimib 30 päeva). Nende linkide abil võib varasemaid postitusi ümber sõnastada ning oma kohalolu foorumis olematuks muuta. Foorumi postituste arhiveerimine teeb võimalikuks ka selle, millele on osutanud $H$. Rheingold (2000), võrreldes interneti kogukondi traditsiooniliste kogukondadega: "kui traditsiooniliselt

$10 \mathrm{Up}$ To You.

11 Kodutute foorumites on ka teemapüstitusi, mille alla postitamine on kestnud aastaid (nt "Viimane raamat" K72 - esimene postitus 27.07.2005, viimane postitus - 17.08.2011 (seisuga 30. aug 2011)). Enamasti on need meelelahutuslikud teemad, mille all iga uus osaleja lisab oma mõtteid ja kogemusi, mitte aga vestlused, kus osaleksid püsivalt ühed ja samad foorumiliikmed. 
me oleme harjunud kohtuma inimestega ja siis nendega tutvuma, siis virtuaalses kogukonnas võid sa enne inimest tundma õppida ja alles siis valida, kas temaga kohtuda."

Erinevalt avalikest kohtumispaikadest väljaspool internetti ei ole foorumis vestluse osapooled füüsiliselt kohal ja neil puudub suulise eneseväljenduse võimalus: "kohtumine" ja informatsiooni vahetamine toimub tekstipõhises keskkonnas. Selle eeliseks on võimalus osaleda vestluses anonüümselt, puuduseks, et oma välimuse, hetkeemotsioone väljendavate näoilmete, häälekõla ja žestidega ei saa anda enda ega oma kavatsuste kohta lisainformatsiooni (vrd ka Blank 2009, 9-10). Teiste usalduse võitmiseks ja enese arusaadavaks tegemiseks saab kasutada vaid emotsioone väljendavat visuaalset märkidekeelt - emotikone, teksti ja varem salvestatud pildimaterjali. Perekooli ja Kodutute foorumite liikmed väljendavad suhtumisi ja kirjeldavad oma välimust foorumi tehnoloogiliste võimaluste abil nagu kasutajanimed, avatarid, pildigaleriid jm (vt täpsemalt "Eneseesitlus ja Rollikäitumine").

\section{Kirjutatud ja kirjutamata reeglid}

Internetifoorumites reguleerivad ja mõjutavad suhtlemist kirjutatud ja kirjutamata reeglid. Nii Perekooli kui ka Kodutute keskkonnas kehtivad veebi riputatud reeglid, mida foorumis osalejad peavad järgima. Nende abil markeeritakse suhtluse piirid, reeglite järgimist kontrollivad moderaatorid ja nn vanad olijad. Teose "Internetipsühholoogia" autor Patricia Wallace on nimetanud sellist reeglite nähtavasse kohta ülesriputamist "sildiks uksel". Tema arvates on sellise käitumise eesmärk kaitsta oma rühma kaose eest, soodustada või lausa nõuda reeglistikuga kohanemist. Ka on P. Wallace täheldanud, et nn netiketi juhised on muutunud rutiiniks ja uustulnukad suunatakse tavaliselt nendega tutvuma (vt Wallace 2002, 93). Perekooli foorumites paikneb reeglistik lingi "Kasutajatingimused" all, Kodutute foorumites alamfoorumi "Reeglid ja abi" teemade "[Oluline] Foorumi reeglid", "[Oluline] Kodutud.com (n)etikett" ja lingi "Kasutajatingimused" all. Foorumi reeglitega määratakse kindlaks suhtlusviisid, kasutajaid informeeritakse nende õigustest, foorumi võimalustest ja piirangutest. Mõlemasse vaatlusalusesse foorumisse on valitud ja kohandatud ülemaailmselt levinud netiketireegleid (vt nt http://www.pm.ee/netikett/, http://www.albion.com/netiquette/), 
mis arvestavad konkreetsete keskkondade vajadusi ja spetsiifikat. Perekooli ja Kodutute reeglid sõnastavad foorumis osalejate ning foorumi haldajate õigused, määratlevad teistesse foorumikasutajatesse suhtumise ja aktsepteeritud suhtluskeele piirid, toimingud uute vestlusteemade loomisel, sõnastavad keelatud teemapüstitused.

Suhtluse regulatsioonid sarnanevad traditsioonilistele kultuuriruumis kehtivatele ühiskondlikele normidele. Näiteks sedastab Kodutute üks reegleid, et foorumis on keelatud Eesti Vabariigi seaduste vastane tegevus - reeglid, mis kehtivad väljaspool internetti, kehtivad ka virtuaalrühmadele. Taunitud on teemapüstitused ja tegevused, mida üldjuhul ka väljaspool internetti sobivaks ei peeta. Perekooli foorumi kasutajad näiteks ei tohi postitada pornograafilisi materjale ega õhutada kasutajaid vihkamisele ja vägivallale, propageerida piraatlust, alkoholi või tubakatooteid. Mõlemas keskkonnas on põlu all narkootiliste ainete kasutamisele ärgitavad postitused, aga ka omavoliline reklaam, Perekooli foorumites kauplemine ravimitega.

Foorumiliikmete keelekasutust ja kirjutamisviise käsitlevad reeglid väljendavad üldlevinud arusaamu kirjutamisest ja keelest (nt Kodutute reegel: "Kirjutada tuleb korrektses ja arusaadavas keeles"), osa reeglitest arvestab üldisemalt internetifoorumeis kirjutamisega, või on kehtestatud just konkreetse keskkonna tarvis. Levinud netiketisoovitus, mis on üles riputatud nii Perekooli kui ka Kodutute foorumireeglitesse, ütleb: “Ära kirjuta foorumipostitustes ja pealkirjades suurtähtedes, võrgus võrdub see karjumisega ja on raskesti loetav." Kodutute foorumid annavad konkreetseid juhiseid teksti liigendamiseks, teistele oma mõtete arusaadavaks vormimiseks, jagavad juhiseid, kui palju on sobilik kasutada emotikone või värvilist teksti, kuidas panna oma mõtted kirja nii, et need oleks teistele võimalikult kergesti arusaadavad. Et Perekooli ja Kodutute foorumid on struktureeritud alamfoorumite kaupa (Perekooli keskkond võimaldas 2011. aasta aprilli seisuga osaleda 14 alamfoorumis, Kodutute keskkond 25 alamfoorumis), siis juhendavad reeglid ka, milliseid valikuid tuleks teha uute foorumiteemade püstitamisel. Mõlemas keskkonnas soovitatakse enne postitama asumist foorumeid jälgida ja lugeda varasemaid postitusi, et vältida lühikese aja jooksul sama teema korduvat postitamist ning saada aimu konkreetse alamfoorumi õhkkonnast ja seal aktsepteeritud teemadest. 
Perekooli reeglid nõuavad, et ühte ja sama teemat ei tohi algatada mitmes alamfoorumis korraga, ning et teema tuleb püstitada õigesse alamfoorumisse.

Viimane rühm reegelid annab ülevaate foorumis osalejate ja meeskonna õigustest. Perekooli keskkonnast saab teada, et kuigi postitusi saavad lugeda kõik külastajad, on postitamisõigus vaid registreerunud kasutajatel. Samuti teavitatakse foorumi kasutajaid võimalustest oma postitusi kustutada või muuta, osaleda kasutajanime all või anonüümselt. Kodutute kasutajatingimused seevastu teavitavad, et Kodutute kontot ei ole võimalik sulgeda, olemasolevaid kuulutusi, arvamusi, kommentaare ei saa kustutada. Samuti on sätestatud, et igal inimesel on õigus ühele kasutajakontole, mitme identiteedi avastamisel tõkestatakse ligipääs foorumisse. Reeglid reguleerivad ka tekstide kasutamist. Nii Perekooli kui ka Kodutute reeglites on kirjas, et nende materjale kopeerides, tsiteerides, levitades tuleks viidata originaalallikale. Nii Perekooli kui ka Kodutute reeglid annavad suurima võimu foorumis meeskonnale: foorumi liikmetel ei ole õigust moderaatorite või administraatorite tegevust kritiseerida ja viimased ei pea oma tegevust kasutajatele põhjendama. Foorumimeeskondadel on õigus ebasobivad, foorumi reeglitega vastuolus olevad postitused kustutada, tõsta valesse alamfoorumisse postitatu ümber teise alamfoorumisse, muuta tekstide sisu, eemaldada sobimatute kasutajanimede all esinevad või kasutajatingimuste vastu eksijad foorumist jm.

Lisaks ametlikele nähtavasse kohta üles riputatud reeglitele kehtib nii Perekooli kui ka Kodutute foorumites rida kirjutamata reegleid ja termineid, millega saab ennast kurssi viia vaid suhtlust jälgides. Vaatlused Perekooli ja Kodutute foorumeis on näidanud, et foorumiliikmete keelekasutus võib olla väga spetsiifiline ning väljast tulijale arusaamatu. Kui näiteks Perekooli beebi alamfoorumi liige lisab oma teemapüstitusele lühendi PBT, siis võib see uustulnukale mõjuda mittemidagiütleva tähekombinatsioonina, foorumi pikaajaline kasutaja aga teab, et lühend tähendab sõnaühendit "Pole beebi teema", ning see on postituse pealkirjale lisatud justkui vabandusena vales alamfoorumis sõnavõtmise eest. Hulk Perekooli vestluste lühendeid on seotud konkreetsete alamfoorumite teemadega. Siinkohal toon näite, milles seletatakse lühendeid lapseootuse alamfoorumi uustulnukale (vt näide 1). 
Näide 1 (P1).

Valik Perekooli lapseootuse alamfoorumis kasutatavaid lühendeid:

(Postitas: GeidiK $(34+5)$, vastus teemale: Olen algaja, palun kirjutage mulle välja, mis need lühendid kõik tähendavad...)

KV-kuklavolt, LA - looteanatoomia, LVU-looteveeuuring, UH - ultraheli, KÜ - kõhuümbermõ̃t, EPK-emakapõhja kõrgus, $A B$ - antibiootikumid, $A D$ - antidepressandid, $P K$ - perekool, $R P$ - rinnapiim, $R P A$ - rinnapiima asendaja, $K T G$ - on aparaat millega vaadatakse loote südame tööd ning emaka tööd, ÄM või $\ddot{A} E$ (olen siin mõlemat varianti näinud) - ämmaemand, OSCAR (One Stop Clinic for Assessment of Risk) - I trimestril tehtav uuring, IVF - kehaväline viljastamine (munarakud viljastatakse seemnerakkudega laboratooriumis)

Kui foorumi ametlikud reeglid üksnes märgivad, et teemad tuleb postitada õigesse alamfoorumisse, siis sellest, mis on õige või vale saab samuti aimu alles foorumi pikaajalisel jälgimisel. Näiteks on Perekooli foorumite vaatlus näidanud, et rasestumise alamfoorumis on taunitud aborditeemad ja mis tahes ajaviitejutud väljaspool alamfoorumit "Ajaviite- ja muud jutud". Siinkirjutaja vaatlused on näidanud, et foorumi ametlikud reeglid ei anna täielikku ülevaadet ka foorumi tehnoloogilistest võimalustest ja kasutajate õigustest. Paar sedalaadi näidet saab tuua Kodutute foorumitest. Esimene neist (K30) seostub kasutajastaatustega (Kollanokk, Algaja, Kasutaja, Auväärne kasutaja ja Friik). Need iseloomustused on kasutajaprofiilide juures kõigile nähtavad. Püsikasutajatele on nende tähendus ilmselge, uustulnukates on need aga tekitanud küsimusi tähenduse ja selle kohta, kes neid määrab. Suhtluse jälgimine ja varasemate postituste lugemine annavad teadmise, et nimetused määrab foorumi tehnoloogia kasutajatele automaatselt, arvestades tehtud postituste arvu (1 postitus - Kollanokk, 2 postitust - Algaja, 100 postitust - Kasutaja, 500 postitust - Auväärne kasutaja, 1000 postitust - Friik, ning et Auväärse kasutaja staatuseni jõudnutel on lisaõigus ise oma staatust kasutajaprofiili all muuta). Pärast põhjalikumat tutvumist selgub, et sarnaselt Perekooli foorumitele on ka mõnes Kodutute alamfoorumis võimalikud anonüümsed postitused. 


\section{Ühised huvid, ajaviited ja sündmused}

Lisaks inimeste omavahelist suhtlust reguleerivatele normidele ja tavadele on igal internetifoorumil aja jooksul kujunenud eripära ja suhtlusviisid, mis sõltuvad sellest, kes on foorumi liikmed, millised on nende soovid ja vajadused. Dave Healy (1997, 61-62) on kirjutanud, et virtuaalrühmad sarnanevad pigem vabatahtliku osalusega spetsiifilistele organisatsioonidele kui sellistele "määratud" traditsioonilistele üksustele nagu perekond, küla, vald vm. Nii Perekooli kui ka Kodutute temaatilised foorumid seovad neid, kes on foorumi internetiavarustest üles otsinud sooviga vahetada informatsiooni ja isiklikke kogemusi, ning vajadusest veeta vaba aega sarnaste huvidega inimeste seltsis. Foorumikohtumistest on saanud alguse kollektiivsed suhtlusviisid, mis on andnud alust traditsioonide tekkeks.

Mare Kõiva $(2009,180)$ on meditsiini teemadele keskenduvate foorumite vaatlusest järeldanud, et neid kasutatakse varasemate perekondlike, sugulus- või territoriaalsete kogukondade aseainena. Sellele tendentsile viitab ka asjaolu, et Perekooli ja Kodutute foorumid võib leida, kui sisestada Google'i (www.google.com) otsingumootorisse sõnapaare "pere foorum" ja "kodu foorum". Foorumite nimetusi ja märksõnu silmas pidades võib ühe foorumis osalemise ajendina näha selle liikmeid ühendavat vajadust virtuaalse perekonna või kodu toetuse järele. ${ }^{12}$ Perekooli foorumitesse koonduvad inimesed on huvitatud vestlemast pereelu, lapse planeerimise, lapseootuse, sünni, lapsekasvatuse, kodu, tervise jm sarnastel teemadel. Kodutute foorumites on inimesi ajendanud kirjutama pereelu- ja (sageli väga intiimsed) suhteprobleemid, kaaslase, sõbra või sõpruskonna otsingud, kuid ka soov leida mõttekaaslasi, kellega vestelda eksistentsiaalsetel või igapäevaelu teemadel.

Katja Laitinen (2003, 250, 256) on juhtinud tähelepanu sellele, et internetile tuginevas kollektiivsuses võib olla küsimus avalikul foorumil asetleidvast isiklike asjade väljendamisest. Ta märgib oma uurimistööga seoses: “... pelk arvuti, kiire internetiühendus või Tori Amose laulude kuulamine ei tee navigeerivatest inimestest veel kollektiivi. Osalemine koosneb jagamisest ja usaldusest." Perekooli ja Kodutute foorumite vaatlus näitab, et lisaks huvile konkreetsete teemade vastu ühendab nende liikmeid see, mida Shawn P. Wilbur

${ }^{12}$ Vajadus virtuaalse perekonna või kodu toetuse järele peegeldub iseäranis Kodutute foorumite teemapüstitustes: "Kes on teie kodutute perekond" (K3) või "Miks oled "kodutu"?" (K41) 
$(1997,13)$ on kirjeldanud kui üht virtuaalse kogukonna alustala kogemuste jagamine, enda, mõne tuttava või lähikondsega toimunu kirjeldamine ja võrdlemine teistega.

Mõlemas keskkonnas on välja kujunenud alamfoorumite kesksete teemadega seotud, ühistest huvidest tulenevad kogemuslood - Perekoolis nt sünnituslood ning Kodutute keskkonnas naljakad suhtelood. Dorothy Noyes (2003, 29-30) märgib, et ühiskonna reaalsus, millega ennast samastatakse, tuleneb ühistest tegevustest. Perekooli ja Kodutute foorumite vaatlus näitab, et inimeste tegevused virtuaalrühmas sarnanevad tegevustele füüsilises maailmas. Informatsiooni ja kogemuste vahetamise kõrval ühendavad virtuaalrühma liikmeid vaba aja veetmise viisid ja igapäevased sündmused. Kodutute foorumites veedetakse aega näiteks kettkirjalaadsete küsimuste-, jutu- ja sõnamängudega (vt näide 2), vestes anekdoote, õuduslugusid, kirjutades üleloomulikest nähtustest ja naljakatest tõestisündinud juhtumistest.

Näide 2 (K2).

Katke Kodutute foorumi kettkirjalaadsest sõnamängust:

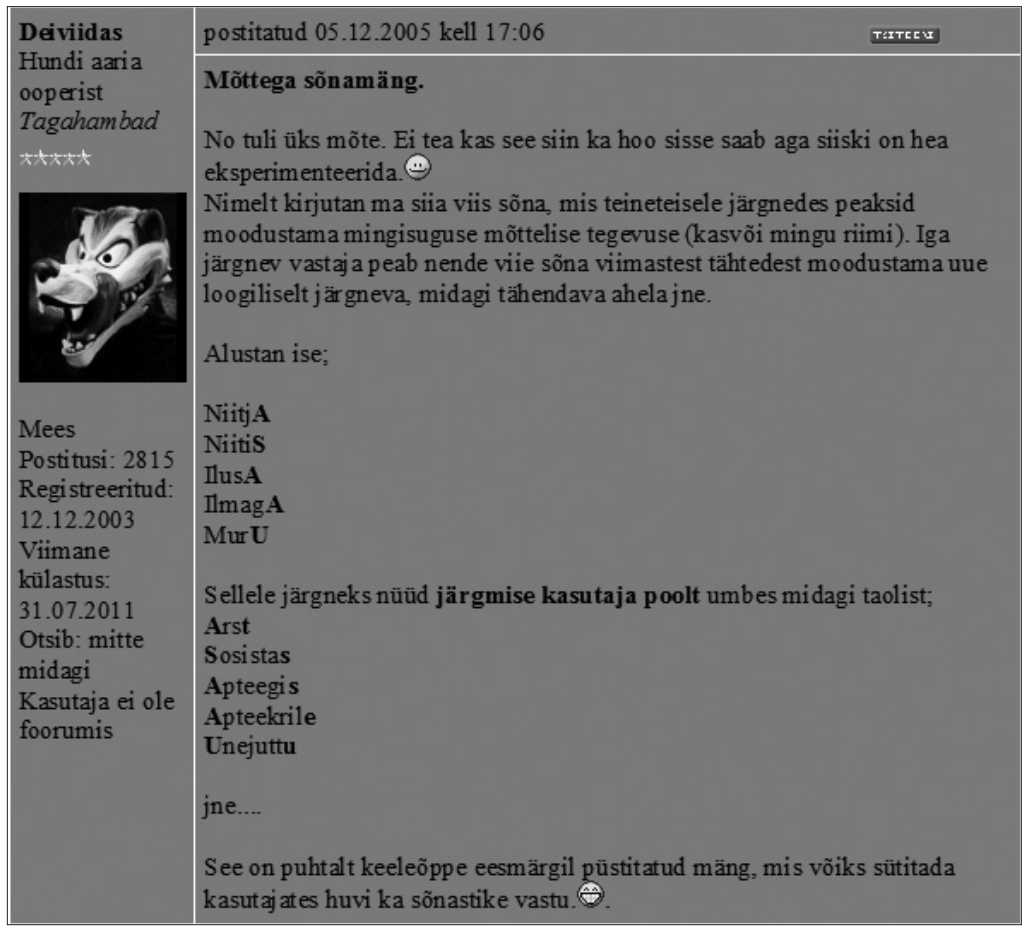


Perekooli foorumites arutletakse päevakajaliste sündmuste, rahvameditsiini, uskumuste, ennete, kalendritähtpäevade ja suhete üle, vahetatakse lõbusaid lugusid laste ütlemistest ja tegemistest (vt lisaks ka Reinaus 2008a). Foorumiliikmeid seovad veel teatud ühised tähtpäevad ja sündmused (vrd Kõiva 2009, 173). Näiteks on Perekooli lapseootuse alamfoorumis tavaks teavitada foorumiliikmeid lapse sünnist ning soovida õnne emale ja lapsele. Kodutute alamfoorumis "Varia" õnnitletakse pikaajalisi foorumiliikmeid sünnipäeva puhul. Mõlema keskkonna foorumites soovitakse kalendritähtpäevadel vestluskaaslastele näiteks head emadepäeva, häid jõule või lihavõttepühi. Kui foorumiliikmete sidemed on piisavalt tugevad ja pikaajalised, võivad neist areneda suhted väljaspool virtuaalset kogukonda (Rheingold 2000). Seda tendentsi kinnitavad Perekooli ja Kodutute foorumid, kuna osa rühma liikmeid on laiendanud oma suhtlust väljapoole internetti.

Näide 3 (K5).

Katke kokkutuleku üleskutsest Kodutute foorumist:

\begin{tabular}{|c|c|}
\hline Autor: & Teema: Kokkutulek: 27. oktoobril Uu etoal! \\
\hline \multirow{2}{*}{ mada } & postitatud 16.08 .2007 kell $20: 38$ \\
\hline & Kokkutulek: 27. okto obril Uuetoal! \\
\hline 4 & $\begin{array}{l}\text { Kallid kaaskannatajad, } \\
\text { Kuna meie kokkutulekud on köigile seni nii meeltmööda olnud, siis arvasin, } \\
\text { et pol eks paha, kui uus üritus juba varsti toimuks. No ja kui juba arvasin, } \\
\text { siis ka broneerisin. Seega, saame kokku } 27 \text {. okt meile juba traditsio oniks } \\
\text { saanud kohas - Tallinna külje all asuvas Uuetoa talus. }\end{array}$ \\
\hline $\begin{array}{l}\text { Mees } \\
\text { Postitusi: } 6104 \\
\text { Registreeritud: } \\
03.05 .2002 \\
\text { Viimane } \\
\text { külastus: }\end{array}$ & $\begin{array}{l}\text { Osavõtumaks on } 356 \mathrm{kr} \text {, selles sisaldub külalistemaja, mõnus saun (isegi } \\
\text { vihelda saab!), hulgaliselt toitu ning lökkekoda, kus koguni suitsu tohib } \\
\text { teha. Hind võib natukene odavamaks muutuda olenevalt inimeste arvust, } \\
\text { kuigi mitte väga oluliselt. Kes alkoholitarbimist pole maha jätnud, peab } \\
\text { loomulikult joogid ise kaasa vedama. Karsklased saavad lihtsamini } \\
\text { hakkama. }\end{array}$ \\
\hline $\begin{array}{l}\text { 16.08.2011 } \\
\text { Asukoht: Tartu } \\
\text { Otsib: mitte } \\
\text { midagi }\end{array}$ & $\begin{array}{l}\text { Nagu iga tähelepanelik kodutu juba eelpooltoodud lingilt märkas, ei saa } \\
\text { Uuetoa just magamiskohtade arvu poolest väga hiilata, mistõttu palun } \\
\text { kõigil, kel võimalik, kaasa haarata matt/madr ats ja magamiskott. }\end{array}$ \\
\hline $\begin{array}{l}\text { Kasutaja ei ole } \\
\text { foorumis }\end{array}$ & Koguneme sinna siis alates kella 17:00st. \\
\hline
\end{tabular}


Perekoolist võib aeg-ajalt lugeda ühel ja samal kuul sündinud laste ja nende vanemate kokkutulekutest, ${ }^{13}$ Kodutute foorumid sisaldavad üleskutseid osaleda foorumivälistel kokkutulekutel lihtsalt lõbusa äraolemise eesmärgil (vt näide 3 ).

\section{Eneseesitlus ja rollikäitumine}

Internetisuhtlus võimaldab väljendada samaaegselt nii personaalset kui ka rühmaidentiteeti (Foster 1996, 27). Perekooli ja Kodutute foorumite liikmeid ühendavad neile keskkondadele iseloomulikud eneseesitlusviisid, aja jooksul kujunenud "meie" tunne ja rollikäitumine.

Dave Healy (1997, 65-66) on kirjeldanud internetti kui "keskmaad", mis lubab indiviididel tegeleda oma ajenditega, mis on seotud nii eraldatuse kui ka seotusega. Howard Rheingoldi (2000) sõnul on suhtlus internetis käsitletav ühtaegu nii "kontakti saavutamise kui ka distantsi säilitamisena". Siinkirjutaja arvates määrab selle internetifoorumitele iseloomulik eneseesitlusviis - inimese soost, vanusest, rahvusest ja füüsilisest väljanägemisest on foorumisuhtluses võimalik aimu saada vaid siis, kui inimene ise soovib need andmed avalikustada, vestluspartnerid võivad jääda anonüümseks ja esitleda end just sellistena nagu parasjagu soovi on (vt ka Reinaus 2008b, 161-163).

Nii Perekooli kui ka Kodutute keskkonnas on kasutajanime valimine foorumi liikmeks saamise eelduseks, ning see kuvatakse vaikimisi kõigi konkreetse isiku foorumipostituste juures. Ühtlasi hakatakse nime taha looma oma võrguisikut sellisena, nagu seda tahetakse teistele foorumiliikmetele näidata. Kasutajanimi võib olla pärisnimi, ka inimese tegelik nimi, viimasest tuletatud või lemmiknimi, samuti meilinimi (nt mailii, kairito, Norah30), suvaline sõna, tähe- või numbrikombinatsioon (nt mjah), iseloomustada kasutaja huvisid või hobisid, perekondlikku staatust, vanust, positsiooni foorumiliikmete seas vm (nt yxikmees) (vt ka Reinaus 2008b, 163). Lisaks kasutajanimele saab Perekooli keskkonnas uue postituse tegemisel täita enesekohased lahtrid "Minu seisund" ja "Kägu". Esimest kasutatakse, et näidata rasedusnädalaid või lapse sünnikuud (nt 24+2, aprillikas), perekondlikku seisu ja laste arvu (Ema 20a10k \& Poja 3a1k.), hetkemeeleolusid (olen kurb) või vestluse edenedes meeldetuletust, kes on selle algataja (teemaalgataja). "Kägu" tähis-

${ }^{13}$ Vt nt "Kokkutulek" (P65). 
tab anonüümset postitajat, ${ }^{14}$ tehes linnukese lahtri "Kägu" ette, ei kuvata foorumiliikme kasutajanime teistele. See on oluline, kuna võimaldab algatada teemasid ja vastata postitustele heitmata ebasobivat valgust varem loodud võrgupersoonile. Kodutute foorumite liikmed saavad kasutajanime kõrval täita lahtreid nagu "Avatar", "Asukoht", "Otsib" ja "Enesekirjeldus". Neile andmetele pääsevad foorumi lugejad ligi, kui klikkavad hiirega postituse juures kuvatud kasutajanimel. Avatar võimaldab foorumiliikmel ennast iseloomustada mõne pildi abil, ülejäänud kolm eneseesitlusvahendit lubavad esitada isikukohast lisainfot (vt näide 4).

Näide 4 (K1).

Kasutajaprofiil keskkonnast www.kodutud.com

Kasutajanimi:

Registreerunud:

Viimane külastus:

Postitusi :

Kasutajatüüp:

Profiili vaadatud:

Kasutajastaatus:

Avatar:

Asukoht:

Otsib:

Enesekirjeldus:

Statistika: ullike

\subsubsection{2 kell 11:33 \\ 25.01.2011 kell 13:50 \\ 3100 \\ Kasutaja \\ 301 \\ naiivitar}

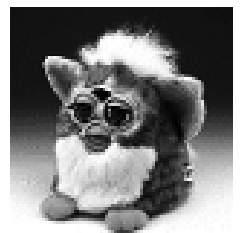

päikese all

mitte midagi

Aina ilusamaks läheb: )

1.02 postitust päevas

$0.64 \%$ kõigist postitustest

Otsi selle kasutaja kõiki postitusi

Saada privaatteade

Lisa sôbranimekiria

${ }^{14}$ Anonüümsed Käod Perekooli keskkonna foorumites on viimaste aastate nähtus. Ajal, mil Reeli Reinaus uuris eneserepresentatsiooni Perekoolis, esineti intiimsemate teemade korral foorumis selliste nimede all nagu "Täna nime ei ütle", "Seekord nimetu" jm (vt Reinaus 2008b, 164). See on asjaolu, mis kinnitab, et mõningate käitumisviiside ja traditsioonide pikaajalise püsimise kõrval on foorumisuhtlus ka pidevas muutumises. 
Perekooli foorumiliikmete enesepresentatsiooni uurinud Reeli Reinaus $(2008 b, 165)$ on märkinud, et peamine eneseloome - olgu see tahtlik või tahtmatu - toimub foorumites kommentaaride või teemaalgatuste kaudu. Kollektiivsuse seisukohast on Perekooli ja Kodutute foorumites ühendavateks eneseesitlusvahenditeks ka rühma ühishuvile keskenduvad kogemuslood (nt sünnitus- ja suhtelood) ning pildialbumid, millele postitustes viidatakse. Mina-jutustustega teavitatakse teisi foorumiliikmeid, milline ma olen, mis on minuga elus juhtunud ja kui hästi ma endaga hakkama saan. Perekooli postitustele lisatud linkidelt võib leida fotosid, kus eksponeeritakse oma lapsi, perekondlikke sündmusi või ennast rasedana (vt ka Reinaus 2008b, 167-169). Kodutute pildigaleriisse lisavad foorumiliikmed oma portreefotosid ning pilte hobidest ja tegemistest - keskkonnas, kus kesksel kohal on partneri- või sõbraotsingud, kannavad sedalaadi fotod olulist informatsiooni.

Suur osa virtuaalrühma kollektiivsuse käsitlusi seostavad seda kujutluse ja tunnetega. Nii iseloomustab Howard Rheingold (2000) virtuaalseid kogukondi sotsiaalsete ühendustena, "mis ilmnevad netis, kui piisavalt inimesi jätkab avalikke diskussioone piisavalt kaua, koos piisavate inimtunnetega, et moodustada veebe isiklikest suhetest kübermaailmas". Katja Laitinen on juhtinud tähelepanu asjaolule, et kollektiivsus on vähemalt teatud määral olemas tundetasandil ja sünnib vaid siis, kui inimesed kogevad end kuuluvat või olevat osa sellest kollektiivist (vt Laitinen 2003, 250). Patricia Wallace $(2002,82)$ märgib, et vaatamata paljude internetifoorumite ajutisele ja haprale natuurile tekib sageli väga tugev rühmatunne, kuigi pole päris selge, miks see ühes seltskonnas tekib, aga teises mitte.

Nii Perekooli kõigis alamfoorumites kui ka Kodutute foorumites on olemas ühisnimetajad, millega rühmaliikmed end oma vestlustes samastavad. Perekoolis on selliseks nimetuseks "perekoolikad", Kodututes "kodutud". ${ }^{15}$ Perekooli keskkonnas olen täheldanud väiksemate siserühmade olemasolu. Näiteks rühmituvad tulevased emad alamfoorumis "Lapse ootamine" lapse oodatava sünnikuu järgi, nimetades end "Minu staatus" lingi all ja pöördumistes rühmakaaslaste poole vastavalt "aprillikad", "maikad", "juunikad" vm. Rühma kontseptsiooni käsitlenud uurijad (vt nt Noyes 2003; Blumenreich, Polonsky 1974) on märkinud, et ükski rühm ei ole

${ }^{15}$ Vt nt "Perekond versus Kodutud" (K60); "Hei-hei perekoolikad" (P66). 
sõltumatu võrgustikust. Perekooli ja Kodutute foorumite liikmete "meie"-tunne kajastub ka teemapüstitustes: "Miks oleme siin?", "Miks oleme need, kes me oleme?" ning "meie" vastandamises ja kõrvutamises teiste sarnaste välis- või siserühmadega (vrd Kõiva 2009, 172). Näiteks esineb Perekoolis kõrvutamist perefoorumiga Pereklubi (www.pereklubi.com) ning Kodutute foorumis suhte- ja intiimteemasid käsitleva ajakirja Maaja jututoas (www.maaja.ee) liikuva seltskonnaga. ${ }^{16}$ Perekooli lapseootuse alamfoorumis "märtsikate", "aprillikate" vm nimetuste all koonduvate foorumiliikmete postitustes esineb "meie" ja "teiste" kõrvutamine nt vestlustes, kus arutletakse teemadel, kui palju meid on, kui hästi meil läheb. ${ }^{17}$

Eneseesitlus internetifoorumis on seotud tuntuse ja teatud staatuse saavutamisega rühmakaaslaste seas. Perekooli ja Kodutute foorumite mõningad pikaajalised liikmed on omandanud teatud laadi rollikäitumise, mida nad kasutavad foorumi suhtluse piiride paikapanemiseks või nende püsimise tagamiseks, teiste seas silmapaistmiseks ning rühmakaaslaste abistamiseks. Patricia Wallace $(2002,139)$ märgib, et mõningates foorumites on sise- ja välisrühma piiriks rühma ajaloo ja normide tundmine. Vaadeldavates foorumites on $\mathrm{nn}$ vanu olijaid, kes on foorumi liikmed selle algusaegadest peale. Neid teatakse foorumi reeglite, tavade ja ajaloo asjatundjatena, moderaatorite kõrval jälgivad nad, et kirjutatud ja kirjutamata reeglid oleksid täidetud. "Vanad olijad" vastavad, kui foorumis küsitakse, kes on Kägu?, "Mis need lühendid kõik tähendavad?" vm. ${ }^{18}$ Uustulnukate postitustele antakse selgitavaid kommentaare või ka negatiivse või etteheitva varjundiga vastuseid, kus vihjatakse teemaalgataja hooletusele varasema suhtluse jälgimisel ja foorumireeglitega tutvumisel. Patricia Wallace $(2002,95)$ on sellist käitumisviisi võrrelnud virtuaalse kulmukortsutamisega. Viimasega tuletatakse reeglirikkujale leebelt või vähem leebelt meelde, et teatud käitumine pole vastuvõetav. Lisaks reeglite ja suhtlusviisidega hästi kursis olevatele püsiasukatele võib foorumiliikmete seas täheldada ka niinimetatud ekspertide kohalolu (vt ka Reinaus 2008b, 166). Perekooli ja Kodutute foorumites tuntakse

${ }^{16}$ Vt nt "Kuhu kõik novembrikad kadunud on?" (P61); "Miks oled kodutu?" (K41).

${ }^{17}$ Vt nt "Aprillikast märtsikaks - poja käes!" (P6); "August, kuidas meil läheb?" (P 27); "Septembrikad;)” (P 26).

18 "Olen algaja, palun kirjutage mulle välja, mis need lühendid kõik tähendavad..." (P1); "Mis teema on Kägudega:D?" (P7). 
eksperte tänu nende spetsiifilistele teadmistele. Need on foorumlased, kes avaldavad oma arvamust igal võimalikul juhul ja/või kelle poole pöördutakse, et ühes või teises küsimuses nõu saada. Näiteks Perekoolis kasutaja Kohalik (emapalga jm küsimused) ja Emand Kaseladvas ${ }^{19}$ (kodussünnituse, loodusliku eluviisiga jmt seotud küsimused), Kodututes foorumi looja, selle ajaloo, reeglite ning tavadega hästi kursis olev Mada. Ekspertidele vastandlikku rollikäitumist esindavad foorumikasutajad, keda olen oma vaatluste käigus nimetanud "saamatuteks". Saamatud on foorumi püsiasukad, kes on rohkete postitustega pälvinud foorumiliikmete tähelepanu, sest nad ei suuda tulla toime oma igapäevaeluga. Kauaaegsete liikmete kõrval võib foorumites täheldada ka nn ajutiste liidrite esilekerkimist. Siinkirjutaja tähelepanekute põhjal on need tugevad isiksused, kes pälvivad teiste tähelepanu ja poolehoiu aktiivse eneseesitluse ja enese avamise kaudu, ning kes hoolitsevad selle eest, et suhtlus ei vaibuks. Liidrite sattumisest mõne kitsama teema arutellu oleneb ajutiste siserühmade tekkimine ja lagunemine. Kui tugev liider lahkub rühmast, on täheldatav liikmete aktiivsuse langus ning rühm võib koost laguneda. ${ }^{20}$ Viimane käitumismuster, mida siinkohal kirjeldada tahan, seostub Perekooli foorumite anonüümsete Kägudega. Käona esinetakse vestlustes, kui kõne all on väga isiklik või piinlik teema. Liisa Vesik $(2008,75)$ on seoses Delfi Naistelehe lemmikloomafoorumiga märkinud, et kuna see on anonüümne, suhtutakse sealsetesse teemaarendustesse teatava põlgusega. Perekooli anonüümsed Käod on aga tuntud ka kui "kurjad Käod" ${ }^{21}$ Nii mõnigi kord kasutatakse anonüümsust teiste foorumiliikmete kritiseerimisel. Et nende kriitika ei ole alati põhjendatud, on viimasel ajal hakatud Kägusid endid hurjutama: "Kurjad Käod metsa, puu otsa!"22

19 Erinevatel aegadel on kasutaja Emand Kaseladvas esinenud Perekooli foorumites ka kasutajanimede all $R r$ ja Muska (vt Reinaus 2008b, 170).

${ }^{20}$ Liidrite roll ajutiste siserühmade tekkimisel ja lagunemisel on iseäranis hästi vaadeldav Perekooli lapseootuse alamfoorumis. Kui liider lahkub foorumist pärast lapse sündi, vaibub ka ülejäänud rühmaliikmete suhtlus, kui liider jätkab oma kogemuste jagamist beebi alamfoorumis, siis järgivad teda ka ülejäänud rühmaliikmed.

${ }^{21}$ Vt nt "Kägu, kukuu?" (P60).

22 "No APRILLIKAD! Lööte kampa?" (P63). 


\section{Kokkuvõte}

Uurimistöö kontekstis nimetab just uurija rühma ja iseloomustab seda (vt Blumenreich, Polonsky 1974, 13-14). Käesolevas artiklis käsitletud teemad ja järeldused virtuaalrühma kollektiivsusest tulenevad pere- ja suhtefoorumeisse kirjutatud kogemuslugudele keskenduvast uurimistööst ning sellega seotud välitöömeetodite ja uurijaeetika küsimustest.

Perekooli ja Kodutute foorumeis liikuvate inimeste kollektiivsust saab kirjeldada järgnevalt: see seisneb: 1) jagatud, teatud spetsiifilise eripäraga, konkreetse veebiaadressiga, anonüümsust võimaldavas ja tekstuaalsusel põhinevas asünkroonilisele rühmavestlusele orienteeritud "paigas" virtuaalmaastikul; 2) rühmasuhtlust reguleerivate reeglite ja tavade olemasolus, teadvustamises ning järgimises; 3) sarnastes huvides (pere- ja suhteteemad), vastastikuses eneseväljenduses - informatsiooni, kogemuste ja narratiivide vahetamises ning usalduses; 4) ühistes vaba aja veetmise viisides ja sündmustes (laste sünnipäevade tähistamine foorumis, kokkutulekud väljaspool internetti jm); 5) konkreetse foorumi eneseesitlusviisides (võimaldavad väljendada nii personaalset kui ka rühmaidentiteeti) ning aja jooksul rühmaliikmete omavahelises suhtluses kujunenud rollikäitumises; 6) "meie" identiteeti alal hoidva, suhtlusreeglite ja tavade kinnipidamist kontrolliva nn tuumikrühma olemasolus.

Foorumiliikmete eneseesitlus- ja suhtlusviiside analüüs kinnitas, et vaadeldud foorumeisse kirjutatud kogemuslood ei ole enamasti (võimalik, et siin on ka erandeid) adresseeritud laiemale avalikkusele, vaid "omadele", sarnaste huvide, kogemuste ja väärtushinnangutega konkreetse virtuaalrühma liikmeile. Sellises kontekstis saab foorumeisse kirjutatud tekste käsitleda privaatsetena ning seetõttu olen järeldanud, et uurijahuvide avalikustamine ja nõusoleku küsimine tekstide tsiteerimiseks on toimingud, mida ei tohi neis foorumeis uurimistööd tehes kergekäeliselt ignoreerida. Nii Perekooli kui ka Kodutute keskkonda kasutajanimede alt kirjutatud delikaatse sisuga tekstid on viinud siinkirjutaja järelduseni, et nende tekstide puhul oleks uurijaeetika seisukohast sobiv küsida nende autoreilt nõusolekut. Küsimuse, kuidas postituse autoriga ühendust võtta, aitab lahendada foorumi tehnoloogiliste võimaluste tundmine. Perekoolis saab postituse autoriga ühendust võtta mõnikord postituse sisule lisatud e-maili aadressi kaudu, Kodututelt 
saab küsida nõusolekut privaatteadete saatmise vahendi U2U abil. Täiesti anonüümsena esitatud tekstide puhul (Perekoolis Kägude tekstid, Kodutute foorumites nt alamfoorum "Seksperdid") võib abi olla foorumi meeskonnaga kontakteerumisest.

Juhul, kui otsus uurijahuvide avalikustamise ja nõusoleku küsimise kohta on tehtud, aitab konkreetse virtuaalkeskkonna tehnoloogiliste võimaluste, rühmas kehtivate ametlike ja mitteametlike reeglite ning eneseesitlus- ja suhtlusviiside tundmine uurijal otsustada ka, kuidas käituda nii, et tekiks usalduslik suhe uuritavatega. Kasulik on teadmine, et erinevalt Perekoolist ei saa Kodutute foorumitesse tehtud postitusi kustutada. St iga märkus, kommentaar, mis uurija selles keskkonnas oma kasutajanime alt teeb, on jääv ning hakkab kujundama foorumiliikmete arvamust uurijast. Näiteks on kogemuslugusid uurides hea teada, millistes alamfoorumites on uurimistööd puudutavad postitused aktsepteeritud. Abi on ka foorumi suhtluskeelt puudutavate reeglite ja tavade tundmisest. Nii nagu foorumi keele (nt kasutatavate lühendite) tundmine aitab paremini mõista kogemuslugude sisu ja kollektiivset situatsiooni, kus neid luuakse, aitab see otsustada, kuidas võiks uurija pöörduda uuritavate poole. Ka teadmised foorumi moderaatorite ja nn vanade olijate positsioonist ja õigustest on abiks - foorumi reeglite vastu eksimise tõttu rühma pahameele alla sattumine või kasutajakonto kustutamine võib takistada uurimiseesmärkide täitmist. Seega tuleks uurimistööd internetifoorumis alustada moderaatoritest ja vanadest olijatest. Fakt, et Perekooli ja Kodutute foorumites on kogemuste jagamine seotud ühishuvide ja vastastikkusega, on juhtinud siinkirjutaja tähelepanu asjaolule, et uurija samastumine foorumiliikmetega ja isiklike kogemuste jagamine uuritavatega võib samuti kontakti saavutamist soodustada. Samas tuleks foorumi poolt pakutavate eneseesitlusvahendite kasutamisel olla ettevaatlik. Uurija, kes otsustab Perekooli keskkonnas esineda kui anonüümne Kägu, ei mõju rühmas kehtivaid rollisuhteid arvesse võttes usaldusväärsena.

Kuna internetifoorumeisse kirjutatud kogemuslugude uurimisega seotud välitöömetoodika ja uurijaeetika küsimused on siinkirjutaja silmis intrigeeriv uurimisteema ja vajab veel põhjalikumat analüüsi, vaatlen neid küsimusi täiendavalt oma teistes käsitlustes (vt nt Pilt 2013). 


\section{Kirjandus}

Anderson, Benedict 1983. Imagined Communities. London: Verso.

Arpo, Robert 2001. Internet-texts and interpretative communities. Perspectives on the cultural construction of Internet-texts. - Nord Nytt 82. Computers \& Culture, 5-35.

Blank, Trevor J. 2007. Examining the transmission of urban legends: Making the case for folklore fieldwork on the Internet. - Folklore Forum 37 (1), 15-26.

Blank, Trevor J. 2009. Introduction. Toward a Conceptual Framework for the Study of Folklore and the Internet. - Blank, Trevor J. (toim). Folklore and the Internet. Vernacular Expression in a Digital World. Logan, Utah: Utah State University Press, 1-20 (http:// digitalcommons.usu.edu/cgi/viewcontent.cgi?article=1034\&context =usupress_pubs -30.01 .2013 ).

Blumenreich, Beth; Polonsky, Bari Lynn 1974. Re-evaluating the Concept of Group: ICEN as an Alternative. - Folklore Forum. Bibliographic and Special Series; 12. Department of Folklore and Ethnomusicology, Indiana University, 12-17 (http://hdl.handle.net/2022/2585 30.01.2013).

Dundes, Alan 2002. Kes on rahvas? Valik esseid folkloristikast. Tallinn: Varrak.

Fernback, Jan 1999. There is a there there: Notes Toward a Definition of Cybercommunity. - Jones, Steve (toim). Doing Internet Research. Critical Issues and Methods for Examing the Net. London. New Delhi: SAGE Publications, 203-220 (http://dx.doi. org/10.4135/9781452231471.n10).

Fialkova, Larisa; Jelenevskaja, Maria N. 2001. Vaimud kübermaailmas. Interneti folkloorisaitide analüüs. - Artikkel VTK raamatust (http:// www.folklore.ee/seminar/fialkova3a.html - 30.01.2013).

Foster, Derek 1997. Community and Identity in Electronic Village. - Porter, David (toim). Internet Culture. Routledge. New York and London, 23-38.

Healy, Dave 1997. Cyberspace and Place: The Internet as Middle Landscape on the Electronic Frontier. - Porter, David (toim). Internet Culture. New York; London: Routledge, 55-72 (http://services.exeter.ac.uk/ cmit/media/texts/porter1996/healy1997_cyberspace_and_place/).

Hiiemäe, Reet 2010. Rollid ja rollikäitumine Interneti esoteerikafoorumites. - Hanni, Helen; Kuperjanov, Maris (koost). Haldjas 15. Pärimus ja Internet. Eesti folkloristide 6. talvekonverents. Teesid. Tartu: EKM Teaduskirjastus. Eesti Kirjandusmuuseumi folkloristika osakond, 5 (http://www.folklore.ee/rl/fo/konve/2011/ftk6/teesid.pdf-30.01.2013). 
Hine, Christine 2000. Virtual Ethnography. Los Angeles; London; New Delhi; Singapore: SAGE Publications.

Kalda, Mare 2009. Geocaching Online and Offline. On Representation of a Game from the Estonian Perspective. - Narratives Across Space and Time: Transmissions and Adaptations. Programme and Abstracts: 15th Congress of the International Society for Folk Narrative Research, June 21-27, 2009 Athens. Athens: Hellenic Folklore Research Centre, Academy of Athens, 131.

Kalda, Mare 2010a. Participant Observation in a Global Village. Intermediary Results at the 2009 ISFNR Congress in Athens. Folklore. Electronic Journal of Folklore 44, 174-176 (http://www. folklore.ee/folklore/vol44/news.pdf - 30.01.2013).

Kalda, Mare 2010b. The Joint Creation of an Informational Environment or Storitelling on the Internet. - Vesik, Liisa (toim). From Language to Mind 4. On the Occasion of the 110th Birthday of Academican Oskar Loorits and 75th birthday of Pille Kippar. Abstracts. Tartu: Department of Folkloristics, Estonian Literary Museum, ELM Scholarly Press, 6 (http://www.folklore.ee/rl/fo/konve/2010/loorits/ teesid.pdf - 30.01.2013).

Kõiva, Mare 2009. Online Medicine. Communication and Narratives. Kõiva, Mare (toim). Media \& Folklore. Contemporary Folklore IV. Tartu: ELM Scholary Press, 162-182 (http://www.folklore.ee/rl/pubte/ ee/cf/cf4/CF4_Koiva.pdf - 30.01.2013).

Kõiva, Mare 2010. Patsiendinarratiivid Internetis. - Paal, Piret (toim). Inimene, tervis ja haigused. Tartu: EKM Teaduskirjastus, lk 217-251.

Kõiva, Mare; Vesik, Liisa 2009. Contemporary Folklore, Internet and Communitites at the beginning of the 21st Century. - Kõiva, Mare (toim). Media \& Folklore. Contemporary Folklore IV. Tartu: ELM Scholarly Press, 97-117 (http://www.folklore.ee/rl/pubte/ee/cf/cf4-30.01.2013).

Laitinen, Katja 2003. Etnograafiliselt loodud kollektiivsus. - Jaago, Tiiu (koost). Pärimus ja tôlgendus. Artikleid folkloristika ja etnoloogia teooria, meetodite ning uurimispraktika alalt. Tartu: Tartu Ülikooli Kirjastus. Tartu Ülikool, eesti ja võrdleva rahvaluule osakond, 248-258.

Noyes, Dorothy 2003. Group. -Feintuch, Burt (toim). Eight Words for the Study of Expressive Culture. University of Illinois Press, Urbana and Chicago, 7-41.

Oldenburg, Ray 1999. The Great Good Place: Cafes, Coffee Shops, Bookstores, Bars, Hair Salons, and Other Hangouts at the Heart of a Community. New York: Marlowe \& Company.

Pilt, Maili 2013. Uurijahuvi - konflikt ja dialoog: “Teistmoodi laste” vanemate lood internetifoorumis. - Kulasalu, Kaisa; Päll, Lona; Rumm, Kaija (koost). Kogemus, taju, keha: uurimusi noorteadlastelt. VanaVaraVedaja nr 8. Tartu, Tartu Nefa Rühm, 160-183. 
Rheingold, Howard 2000 [1993]. The Virtual Community: Homesteading on the Electronic Frontier [2. väljalase] (http://www.rheingold.com/ $\mathrm{vc/book}-30.01 .2013)$.

Reinaus, Reeli 2008a. Pärimusliku ainese teke ja areng Perekoolis ning selle avaldumisvormid. - Mäetagused 38, 33-54 (http://www.folklore.ee/ tagused/nr38/reinaus.pdf - 30.01.2013).

Reinaus, Reeli 2008b. Enesepresentatsioon Perekoolis. - Hiiemäe, Mall; Saarlo, Liina (toim). Tonditosin. Pro Folkloristika XIV. Tartu: Eesti Kirjandusmuuseum, 160-182.

Reinaus, Reeli 2008c. Keha kui eneserepresentatsiooni vahend sünnituslugudes. - Hiiemäe, Mall; Saarlo, Liina (toim). Tonditosin. Pro Folkloristika XIV. Tartu: Eesti Kirjandusmuuseum, 182-200.

Roberts, Lynne; Smith, Leigh; Pollock, Clare 2004. Conducting Ethical Research Online: Respect for Individuals, Identities and the Ownership of Words. - Buchanan, Elisabeth A. (toim). Readings in virtual research ethics: issues and contraversies. Hersey; London; Melbourne; Singapore: Idea Group, 156-173.

Vesik, Liisa 2008. Lemmikloomad Eesti veebis viimasel viiel aastal. Mäetagused 40, 69-82 (http://www.folklore.ee/tagused/nr40/vesik. pdf - 30.01.2013).

Vesik, Liisa 2010. Estonian Websites Dedicated to Pets. - Vesik, Liisa (toim). From Language to Mind 4. On the Occasion of the 110th Birthday of Academican Oskar Loorits and 75th birthday of Pille Kippar. Abstracts. Tartu: Department of Folkloristics, Estonian Literary Museum, ELM Scholarly Press, Tartu, 20 (http://www.folklore.ee/ rl/fo/konve/2010/loorits/teesid.pdf - 30.01.2013).

Wallace Patricia 2002. Internetipsühholoogia. Rollid elus ja internetis. Tallinn: Valgus.

Wilbur, Shawn P. 1997. An Archeology of Gyberspaces: Virtuality, Community, Identity. - Porter, David (toim). Internet Culture. New York; London: Routledge, 5-22. 


\section{Summary}

\section{Internet Forum as a Meeting Place. Insights into Virtual Group Collectivity}

Keywords: folkloristic fieldwork, internet forum, collectivity, "locations" on virtual landscape, research ethics, virtual group

The author's interest in virtual group collectivity grew out of the treatment of the issues of fieldwork methodology and research ethics in a research focusing on personal experience stories on internet forums concerned with family and relationship topics. Due to accessibility of internet forums, they may be viewed as public spaces; at the same time, the private content of experience stories and the highly personal and sensitive information contradicts the openness of the forum. So, there is possibility that the writers have not realised that their texts could be objects of a research and therefore become public outside the concrete virtual space (cf. also Roberts, Smith, Pollock 2004, 161).

The article dwells upon the manifestations of collectivity in virtual groups, in order to understand the socio-cultural context of the forum texts. Also, it attempts to find answers to the question how a researcher should behave when communicating in forum environments and/or when collecting texts featuring people's experiences, feelings and attitudes by way of observation. Therefore, the term "meeting place" is used in two meanings, denoting both the everyday communication space for the virtual group and the "field" in which the researcher and the research subjects meet. The article is based on the analysis of forums on two Estonian internet websites, Perekool (Family School) (www.perekool.ee) and Kodutud (Homeless) (www. kodutud.com).

In the context of the current approach to the problem, the collectivity of the virtual group can be described by the following features: 1) a "location" in virtual landscape, which is shared, has certain specificity, a concrete internet address, allows for anonymity, is based on textuality, and is orientated to asynchronous group discussions; 2) existence, awareness and observation of rules and traditions regulating group behaviour; 3) similar interests (topics related to family and relationships), mutual self-expression - trust and exchange of information, experience and narratives; 4) joint events and ways of spending free time (celebrating children's birthdays on forums, meetings outside Internet, etc.); 5) ways of self-presentation on concrete forums (expressing both personal and group identity) and role behaviour in the communication between group members, which has 
been formed throughout time; 6 ) existence of so-called core group, which preserves the "we" identity and controls the observation of traditions and communication rules.

The analysis of forum members' ways of self-presentation and discussions proved that the majority of the personal experience stories shared on the forums of Perekool and Kodutud are not addressed to the general public (there can, of course, be exceptions) but rather to the peers - members of a concrete virtual group with the same interests, experience and values. In this context, the texts written on forums can be regarded as private and therefore it can be concluded that disclosing research interests and asking for consent to cite the texts is something that cannot be ignored while doing research on these forums. The delicated content of the personal experience stories in the Kodutud and Perekool environments has led the author to the conclusion that, from the point of view of research ethics, the posters should be approached individually. The issue of getting in touch with the writer of a concrete post can be solved by technological means of the forum. Sometimes the Perekool website provides e-mail addresses, whereas on Kodutud website a private message can be sent by U2U device. In case of completely anonymous texts the forum administration should be contacted.

If a researcher has made a decision about disclosing the research interests and asking for permission, knowledge of the technological options in the virtual environment, the official and unofficial rules within the group as well as ways of self-presentation and communication help to decide how to behave in order to establish an intimate relationship with research subjects. It is good to know that, unlike in Perekool, the posts on Kodutud forums cannot be deleted. This means that each remark and comment made by the researcher under his/her own username is permanent and contributes to the opinion of the forum members about the researcher. For instance, when investigating personal experience stories, it is useful to know which sub-forums accept posts relevant for the research. It is also helpful if you know the rules and traditions of the communication language (e.g., abbreviations) on the forum, which contributes to the understanding of the content of experience stories and the collective situation in which they are created, and helps to decide how the researcher should turn to the research subjects. Also, knowledge of the position and rights of forum moderators and so-called old-timers comes in handy, as breaking forum rules and deserving resentment from the group or erasing the user account might hinder research. Therefore, research on an internet forum should be started from moderators and old-timers. The fact that sharing experience on Perekool and Kodutud forums is associated with common interests and mutuality, has made the author think that the researcher's identification with forum members and sharing personal experience with the research subjects could 
contribute to establishing contacts. Also, by considering the role relations in a group, the researcher can decide which means of self-presentation would be suitable in introducing him/herself to the research subjects. 


\section{MAAILM ja \\ MULTITASKING}

\section{Koostanud ja toimetanud MARE KÕIVA}

http://www.folklore.ee/rl/pubte/ee/cf/multi

ISBN 978-9949-544-01-1

Tartu 2014

Trükis ilmunud:

MAAILM ja MULTITASKING. Tänapäeva folkloorist 10.

Tartu 2014

Sarja peatoimetaja: Eda Kalmre

Kogumiku koostaja ja toimetaja: Mare Kõiva

Keeletoimetaja: Asta Niinemets

Kaanekujundus: Lilli-Krõõt Repnau

Küljendus: Diana Kahre

HTML: Diana Kahre

Trükist toetasid: teadusteema SF 0030181s08, ETF grant nr 8137 ja IUT22-5 ning Eesti Kultuurkapital.

E-raamatu valmimist toetas: EKKM14-344 Eesti keele, kultuuri ja folkloori kasutusalade laiendamine ja tutvustamine elektroonilistel infokandjatel.
(C) Mare Kõiva
(C) autorid
(C) EKM Teaduskirjastus 2014 